\title{
The Encyclopedia of Virtual Art Carving Toraja - Indonesia
}

\author{
Lande Sudianto ${ }^{1, *}$, and Petrus Simon ${ }^{2}$ \\ ${ }^{1}$ Program Study of Electrical Engineering, Paulus Chrystian University of Indonesia, Jl. Perintis Kemerdekaan Km. 13, \\ Makassar, 90243, Indonesia \\ ${ }^{2}$ Program Study of Management, Paulus Chrystian University of Indonesia, Jl. Perintis Kemerdekaan Km. 13, Makassar, 90243 , \\ Indonesia
}

\begin{abstract}
The unity of local culture in Indonesia is the national culture which represented the identity of Indonesia. There are many cultural resources of our nation which needs to preserved and improved to maintain the national identity of Indonesia. The art of crafting from Toraja contains value and philosophy which based on the values of local wisdom as the part of Toraja and national culture. The application of Virtual Encyclopedia of Toraja Crafting Art which based on information and communication technology (ICT) is developed in order to integrate the culture in education for preservation, improvement, and education of cultural noble values for Indonesia especially the culture of crafting art in Toraja. There are 128 kinds of Toraja crafting which are divided into four groups: i) Garontok Passuraq; ii) Passuraq iii) Todolo; iv) Passuraq Malollek; v) Passuraq Pakbarean. Toraja crafting has denotative and connotative meaning. The explicit and implicit meanings in Toraja cultural make the Toraja culture become very interesting and challenging. The explicit meaning of Toraja crafting is called denotative meaning which is objective. Meanwhile, the implicit meaning of Toraja crafting is called connotative meaning which is subjective.
\end{abstract}

Key words: Carving, encyclopedia, ICT, Toraja, virtual.

\section{Introduction}

Indonesia has a local cultural diversity that can be used as an asset that cannot be equated with the local culture of other countries. Indonesia's local cultures vary in each region. Each region has its typical culture, such as traditional houses, traditional clothes, traditional dance, music, art carving/sculpture and others. All that can be used as a power to be able to strengthen the resilience of the nation's culture in the eyes of the International. Local cultural distinctiveness is often interesting views of other countries. Proven many foreign tourists trying to learn Indonesian culture such as learning a dance typical of a region or looking for craft items to be used as a souvenir. This proves that the culture of Indonesia has a unique characteristic. Local cultural unity that Indonesia is a nation's culture that represents the identity of the Indonesian state. To that end, local culture should be maintained and inherited properly to the nation's culture remained firm. Public awareness to keep local cultures today still fairly minimal [1, 2].

Integration of culture in the learning values is one of the themes discussed by the commission VIII in National Consultation, Ministry of Education and Culture in 2012 were held in Sawangan, Depok-West Java, Indonesia on 26 to 28 February 2012. One of the issues that need attention in the current era of globalization is a matter of national identity. Swift influence of foreign culture in the era of globalization is a threat to national security. Many of our cultural values are very high value but not recognized, let alone implemented. If this is allowed to continue, the next generation would lose its identity as a nation of Indonesia. Cultural wealth of the nation very much needs to be preserved and developed with the aim to strengthen the national identity (national identity), maintaining the philosophy of the nation Pancasila and the motto 'unity in diversity (cultural diversity), to strengthen the community (social cohesion), fostering a culture of peace (culture of peace), forming a national character (character building) and make

\footnotetext{
*Corresponding author: sudianto@ukipaulus.ac.id
} 
referrals culture (standard setting) [3]. Awareness of culture gave way to the realization of national identity in accordance with the noble values of national culture and creates a climate conducive and harmonious so that the values of local wisdom will be able to respond in a positive and productive modernization in line with national values. In line with this is the problem of culture in re-emphasized in the discussion of the theme "Preserve and Strengthen Cultural Indonesia" by commission IV on the National Ministry of Education and Culture 2013 held in Sawangan on 10 to 13 February 2013.

In the Strategic Plan 2010 to 2014 of the Ministry of Culture and Tourism has registered two nominations culture of the region as a world cultural heritage, namely: "The Cultural Landscape of Bali Province" (a temporary number 1194C) and "Tana Toraja Traditional Settlement" (a temporary number 1038C), so that the necessary efforts to preserve and develop the cultural arts [4-7]. Traditional decoration is a source of cultural information, because it can be used to determine the background of the cultural and natural history of the public mind of the wearer. Decorative arts, also expressed the values espoused and nurtured and procedures applicable in community life [8]. Similarly, the decorative carvings Toraja that are well known to foreign countries. Not only the beauty of the motifs, but also the culture behind them. Decorative arts Toraja is one embodiment of the values of trust Todolo. To the Toraja people will never lose its culture during the traditions and values of the old custom (Todolo) maintained in public life. In addition, the process of cultural inheritance that has lasted for centuries is always rooted in the culture of the past grandeur. Tana Toraja is expected to overcome the transition period by means of an inventory of cultural and learn about the richness of the traditional culture, dwindling resources. Therefore we need a culture of Toraja conservation efforts in the form of decorative carving Toraja documentation contained therein wisdom values and its existence.

\section{Literature review}

On 26 to 28 February 2012, the Ministry of Education and Culture held a national consultation as the first step in formulating policies in the development of education and culture in Indonesia, in the national consultation, the commission VIII discusses the integration of culture in education. The discussion stated that the rationale of integration of culture in education, among others [3]:

(i). Many of the values of our culture are very high value but not recognized, let alone implemented;

(ii). If this is allowed to continue, the next generation would lose its identity as a nation of Indonesia;

(iii). Cultural wealth of the nation very much needs to be taught (integrated) in units of subjects ranging from early childhood, basic education, high school and universities;

(iv). Integration of the wealth of cultural values can be implemented in the form of games and performances are played directly by learners.

With the problems and obstacles encountered are:

(i). Uncharted cultural values that originate from local wisdom.

(ii). Has not formulated values that need to be internalized;

(iii). Charge of cultural values in the curriculum has not been adequate;

(iv). The swift influence of foreign culture in the era of globalization.

The opportunities and potential are:

(i). Many cultural values that originate from local wisdom

(ii). Every ethnic indigenous knowledge which has noble values;

(iii). There is a similarity in meaning between one region to another;

(iv). Internalization of cultural values can enrich the curriculum based on local content;

Based on the results of the national consultation, the commission 8 provide solutions and recommendations as follows:

(i). Urgent need mapping noble values that exist in each ethnic/regional

(ii). Formulate the noble values of each ethnic/areas that can be lifted into a noble cultural values of national culture

(iii). Incorporate cultural values noble nation Indonesia in the education curriculum from primary to higher levels, as well as non-formal education.

Encyclopedia is one of the media education are quite popular among people who are reliable accuracy, some types of encyclopedias such as books and electronic media available. But in Indonesia is less socialized and perhaps the cost is quite expensive, so this encyclopedia is rarely used and there were only a few fruits. With the virtual encyclopedia software can help develop interest in learning to use the educational tools [9-11]. The word encyclopedia is derived from the Greek, namely enkyklios and peideia, which means a work that contains information on all branches of science or explanation comprehensive of branches of science, usually in the form of articles are arranged alphabetically and sometimes by subject [12]. Encyclopedia system is processed to meet the information needs of the general and complex nature, the information obtained can be ensured accuracy. Globally result of information obtained from the encyclopedia would be support in the learning process to achieve a form of active learning pattern.

Some kinds of encyclopedia have specific objectives, but basically an encyclopedia aims to provide information in the form of data that has been processed in such a way so as to include a field of science in depth. For example, cultural encyclopedia aims to provide detailed and complete information about the entire cultural diversity based on the group 
and nail-values of local wisdom that contained in it. In general encyclopedia published more in the form of a book (hard cover), so the lack of appeal in addition to the sale price is relatively expensive (Figure 1).

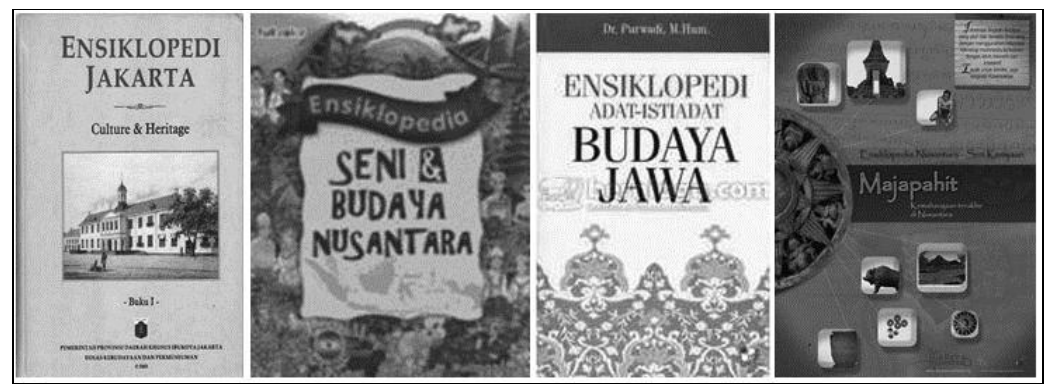

Fig. 1. Books encyclopedia culture.

Virtual encyclopedia is innovative blend of multimedia-based encyclopedia with utilization of ICT technology. By utilizing the Internet network so that the content encyclopedia can be stored and accessed by users. With multimediabased encyclopedia will culture and more attractive, inexpensive, and informative as in use can interactively with users.

\section{Research method}

Stages of development of the system was made with the approach of the paradigm of the System Development Life Cycle (SDLC) which includes five phases: (i) identification of the needs of the system; (ii) analysis and modeling system; (iii) creation of the system; (iv) testing and improvement of the system; and (v) implementation (Figure 2) [13, 14].

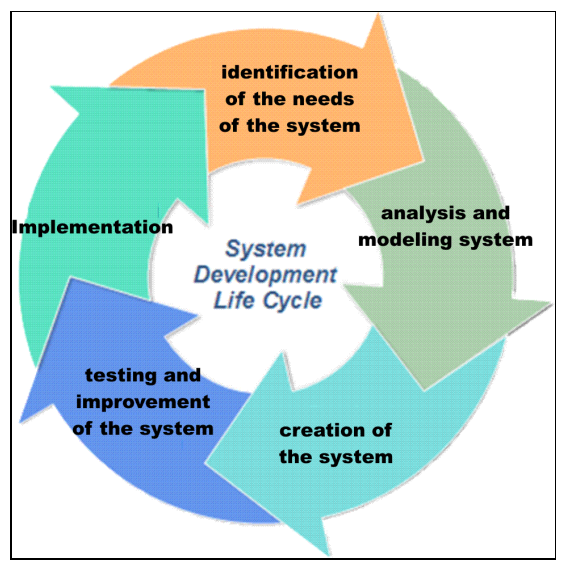

Fig. 2. Paradigm system development life cycle.

Phase identification of the needs of the system, beginning with the preparation of the instruments in the form of research: interview guidelines and support tools such as tape recording, digital cameras, camcorders (video recording), transport equipment and supporting software. Further data collection directly or indirectly. Directly in the form of a survey to study sites for inventory types of existing motif and interviews with relevant parties, among others: craftsmen carving, indigenous stakeholders, government and manager's museum/cultural heritage. Indirectly in the form of literature through literature books and the internet. Data were obtained at this stage in the form of documentation and information about the various types, meaning and purpose, the rules of the use of carving Toraja. Surveys will be conducted in two districts of Tana Toraja and North Toraja district.

Phase analysis and modeling systems, performed analysis and modeling systems with flow map to determine the functions or activities that will be implemented in the system. Flow system folder is created in the form of context diagrams, data flow diagrams, entity relationship diagram, relationships between files, the file structure, the structure of the program, the menu structure, the input format and output format. Analysis and modeling of the system is based on quantitative data and attributes of each motif carving Toraja. Stage of the manufacturing system, the process of making software systems Encyclopedia of Virtual Art Carving Toraja in full using the techniques of the Unified Modeling 
Language (UML), the choice of program packages that are suitable to establish the feasibility of the analysis system. UML techniques used by the technology used. Stage testing and repair systems, testing systems Encyclopedia of Virtual Art Carving Toraja is based on WEB technology.

\section{Results and analysis}

As one of the largest ethnic groups in South Sulawesi, Toraja have a culture in the form of art carvings are beautiful and full of philosophy. Art carved carving Toraja is typical Malay tribes Toraja in South Sulawesi. This engraving printed using special carving tools on a wooden plank, pole traditional house, window or door. Carving Toraja is one of the national cultural wealth it contains a lot of values and philosophy Toraja culture rooted in the values of local wisdom. Toraja motif inspired by a variety of things, such as folklore, objects in the sky, the sacred buffalo, pigs, household appliances, plants and others. These things by the Toraja indeed sacred [15].

Carving Toraja also called passuraq by the Toraja people is a form of sculpture that is printed with a special carving tool on a wooden plank, pole house, window or door. Carving Toraja not only as an image which was created to adorn a form or object or Tongkonan (Toraja traditional house), all kinds of engraving was born out of the sense of a matter of life or social life as well as the ideals of community life, so the entire carving present has meaning in [6, 16]. Carving Toraja contains values, among others:

(i). Economy, some kind of carving Toraja also used as a commodity that bring economic benefit to society;

(ii). Preservation of tradition, carving Toraja is a valuable ancestral heritage which has an important role in the execution of traditional ceremonies.

(iii). Symbol, this value is reflected in the use of decoration by the public for something symbolic.

(iv). Art, carving Toraja a variety of art objects beautiful views and has a sacred value.

(v). Social class, for the people of Toraja, having carved with a particular motif is a pride and express social status in life.

According to the history of engraving at first only known to four forms the base image (symbol) is the epitome of four principal human life, and than applied to Tongkonan home with the intention to remain a concern and always remembered by the public. Therefore installation engraving is not placed at random places on Tongkonan building or house, but installed in the view and philosophy of life Toraja (aluk sanda pitunnna). There are approximately 130 motifs passuraq images ever created, each of which depict the reality of life and there are 75 devoted solely to Tongkonan motive. Based on the results of recent research, there are approximately 67 decoratives carving Toraja of which are in the walls of the Toraja traditional house or household appliances. Nevertheless, ethnic Toraja still classify images passuraq into four categories based on customary provisions $[4,17,18]$.

(i). Garontok Passuraq, the main image and is regarded as the base or foundation for understanding the culture of Toraja, among others: Pa 'Barre' Allo, $\mathrm{Pa}$ 'Manuk Londong, Pa' Tedong and $\mathrm{Pa}$ 'Sussu'.

(ii). Passuraq Todolo, namely engravings concerning equipment considered has merit ceremony for the wearer, among others: $\mathrm{Pa}$ 'Erong, $\mathrm{Pa}$ ' Ulu Karua, $\mathrm{Pa}$ 'Doti Langi' $\mathrm{Pa}$ 'Sometimes Pao, Pa' Barana 'Pa' Bai, Pa 'Lolo Tabang, Pa' Leaf Bolu, Pa 'Leaves of Paria, Pa' Bombo Wai, Pa 'Kapu' Baka, Pa 'Tangke Lumu' Pa 'Bungkang Lake, Pa' Lolo Paku, Pa 'Tank' Pattung, Pa 'Bulintong Pa 'katik, Pa' Talinga Tedong, and others.

(iii). Passuraq Malollek, which are widely used carved carve buildings that do not have a customary role (Tongkonan Stone A'riri). This engraving is used as a symbol of the attitudes and social behavior or relationships with institutions is limited by ethical and moral. Sometimes these engravings no linkage meaning and significance by carving Passura 'Todolo, among others: Pa' Sala'bi 'Pa' Horns Ra'pe, $P a$ 'brought instantly Pare, Pa' Flower Kaliki, Pa 'Poya Munda, Pa' Bulintong Siteba 'Pa' Bulintong Situru 'Pa' Karrang Longa, Pa 'Board Kandaure, $P a^{\prime}$ 'Passulan, $P a$ 'Sepu' Torongkong, and others.

(iv). Passuraq Pakbarean, interpreted as representing a variety of different kinds of life associated with an atmosphere of fun and excitement in childhood. Passuraq Pakbarean an engraving consisting of pieces of the same shape there are those that are straight and curved form, among others: $P a$ 'Bannangan, $P a^{\prime}$ Barra'-barra', Manik Bu'ku Pa' Pa 'Ara' Dena 'Pa' Komba Kalua 'Pa' Bua Kapa 'Pa' Gayang, and others.

To carve carving Toraja using colors consisting of natural color carries meaning and significance for the people of Toraja, which is in accordance with the philosophy of life and the development of human life Toraja. Therefore, the use of color on the engraving should not be changed or altered in usage. Passuraq color material called litak which is the basis for the Toraja people of color are: red (litak mararang), white (litak Mabusa), yellow (litak mariri), black (litak malotong).

Red and white is the color of blood and human bones that symbolizes human life. The colors can be used anywhere in time of traditional ceremonies and in everyday life. The yellow color is the color of glory as a symbol of divinity that is used during the ceremony Rambu Tuka' for the sake of human salvation. Being black is a symbol of death or darkness used during the ceremony Signs Solo' (funerals). Meaning black at the base of each passuraq (engraving) is that the life of every human being overwhelmed by death because, according Todolo Aluk view that the world is only a place to sleep alone or a place to stay temporarily. All colors Passuraq as mentioned above is the color of nature because the material from the ground, except for the black color of charcoal taken from the pot. The use of this material is more durable against the weather and climate in comparison with the color of the synthetic material. 


\subsection{Motif carving Toraja}

Toraja motif consisting of various types, among others: Neq Limbongan, Toraja people believe that the name is taken from the name of their ancestors alive Limbongan estimated at $3000 \mathrm{yr}$ ago. While neq means "lake", Limbongan means springs that never dry so that it becomes a source of life. This motif is interpreted that the fortune came from four corners like springs that are united in the lake and give happiness (Figure 3a). Paqbarre allo, Bare means "circle", and allo means "sun". This type resembles carving circle with a radiant sun rays. This engraving is defined as the knowledge and wisdom that illuminates like the sun (Figure $3 b$ ).

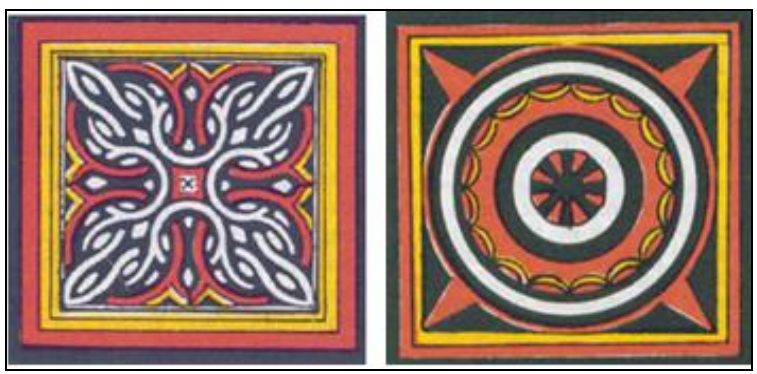

Fig. 3. Motif Neq Limbongan and Paqbarre allo.

\subsection{Torajapedia}

Torajapedia is a virtual encyclopedia of software applications built with technology web based PHP and MySql. (Figure 4 to 8$)$.

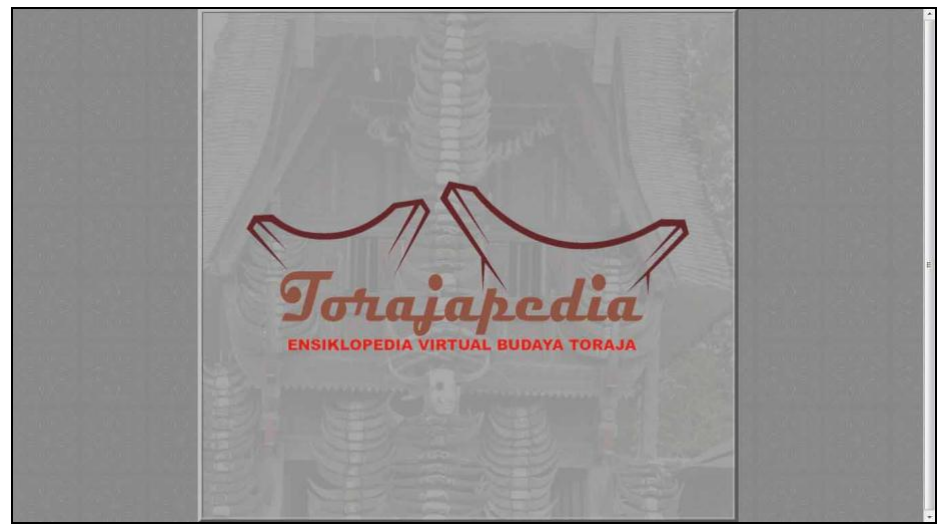

Fig. 4. Front page view Torajapedia. 


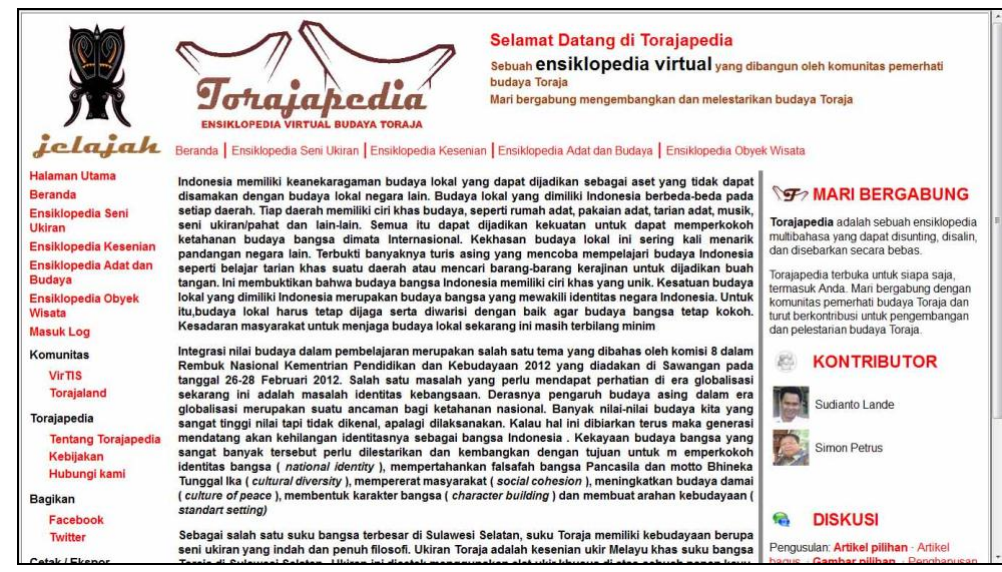

Fig. 5. The main menu display Torajapedia.

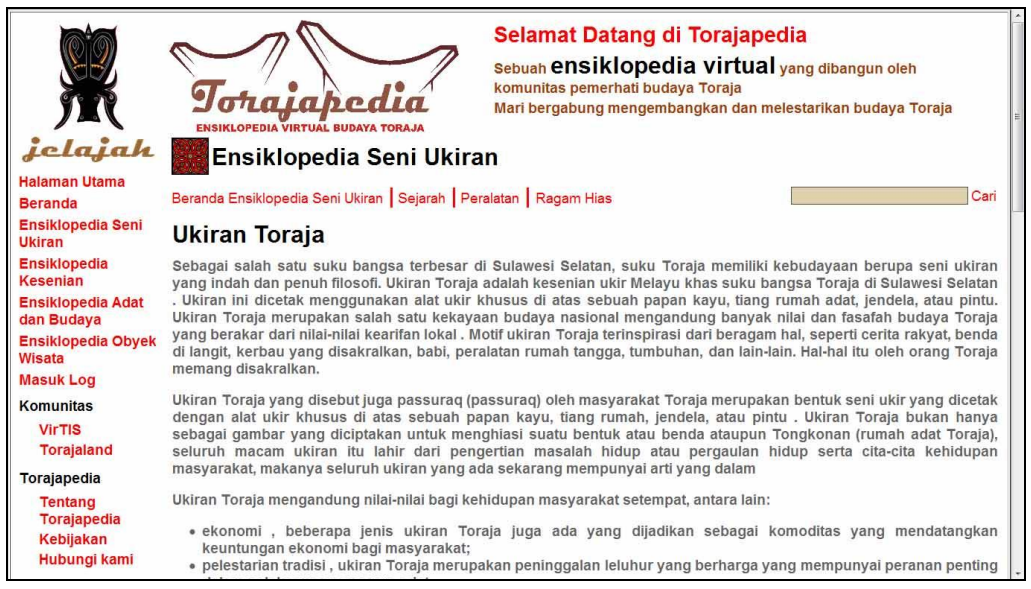

Fig.6. Display carving art encyclopedia Torajapedia.

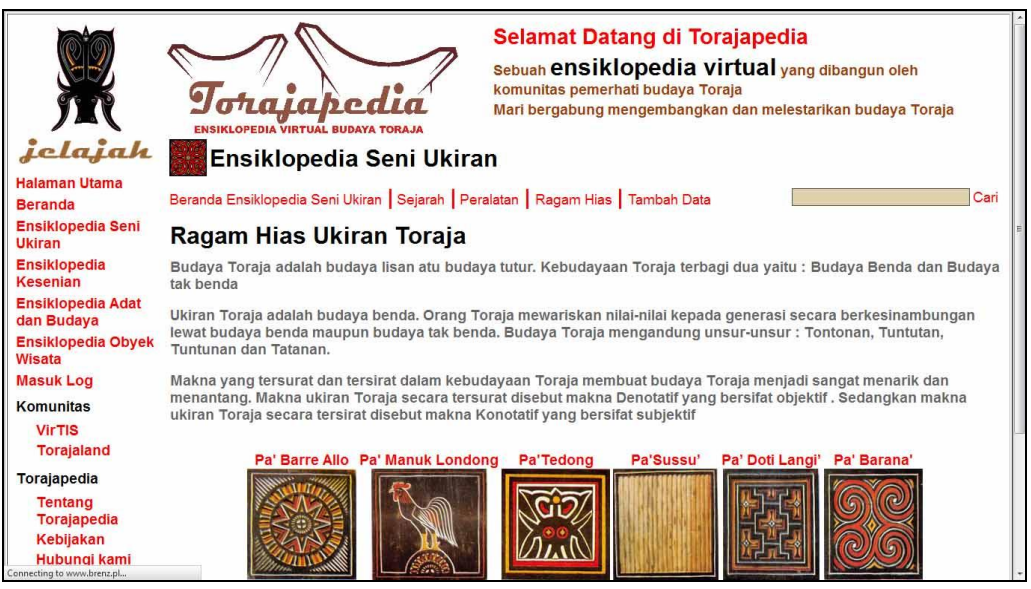

Fig. 7. Display decorative carving Toraja. 


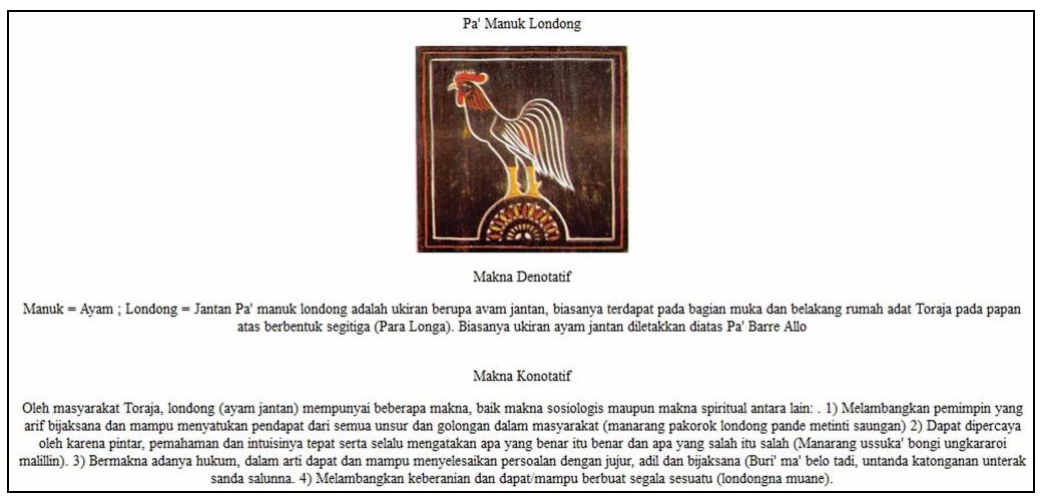

Fig. 8. Display popup_window carved image and meaning.

\section{Conclusion}

There are 130 decoratives carving of Toraja which are divided into four group, namely: i) Garontok Passuraq; ii) Passuraq Todolo; iii) Passuraq Malollek; iv) Passuraq Pakbarean. Toraja carvings have denotative and connotative meanings. The explicit and implicit meanings in Toraja culture make Toraja's culture become more interesting and challenging. The explicit meanings are objective and called denotative meanings while the implicit meanings are subjective and called connotative meanings. Toraja Carving Art Encyclopedia application is developed using PHP and MySQL database program which run optimally on a variety of platforms and browsers that supports multimedia applications. Toraja Carving Art Encyclopedia application helps the user to identify and understand about art and decorative Toraja carving easily.

\section{References}

1. M. Abdul. Integrasi nilai-nilai kearifan lokal dalam pembelajaran untuk menanamkan nasionalisme di sekolah dasar. [Integration of values of local wisdom in learning to infuse nationalism in primary schools]. Proceding Seminar Nasional Lembaga Penelitian UNY (Yogyakarta, 2010). [in Bahasa Indonesia]. p. 1-10. http://scholar.googleusercontent.com/scholar?q=cache:bmGdE6-36gIJ:scholar.google.com/\&hl=en\&as sdt=0,5

2. S. Erman, H. Hasriyanti, A. Fatchan, I.K. Astina, S. Sumarmi. Journal of EFL, Linguistics, and Literature, 1(1): 17-23 (2016). http://www.efljournal.org/index.php/efljournal/article/view/6

3. Ministry of Education and Culture Indonesia. Rencana strategis (renstra) Kementerian Pendidikan dan Kebudayaan. [Strategic plan Ministry of Education and Culture], Jakarta: Kementrian Pendidikan dan Kebudayaan (2010). [in Bahasa Indonesia]. pp. 83-104. https://www.kemdikbud.go.id/dokumen/Renstra\%202015-19/renstra.rar

4. UNESCO, Evaluations of cultural properties. International Council on Monuments and Sites (ICOMOS), Paris: UNESCO (2001) pp. 87-90. http://whc.unesco.org/archive/2001/whc-01-conf205-inf4e.pdf

5. N. Sitonda. Toraja warisan dunia. [Toraja world heritage]. Makasar: Pustaka Refleksi (2007). [in Bahasa Indonesia]. p. 20-26.

https://books.google.co.id/books/about/Toraja.html?id=7X5RIwAACAAJ\&hl=en\&output=html_text\&redir_esc=y

6. S. Luekveerawattana. Procedia - Social and Behavioral Sciences, 65:387-396 (2012). https://www.sciencedirect.com/science/article/pii/S1877042812051245

7. K. Matsuura, Z. Xinsheng, F. Bandarin. The State of world heritage in the Asia-Pacific region 2003. United Nation: UNESCO (2004). p. 17. http://whc.unesco.org/document/4968; http://whc.unesco.org/en/series/12/

8. A. Duli. The Journal of Archaeology, Consciousness and Culture 8(1):3-20 (2015). http://www.tandfonline.com/doi/abs/10.1080/1751696X.2014.993235

9. E. Widiyantara. Perancangan media pembelajaran berbasis multimedia pengenalan seni dan budaya Indonesia pada SD Negeri Blumbang Banjararum Kalibawang Kulon Progo. [Design designing learning multimedia introduction to Indonesian art and culture in State Primary Schools Blumbang, Banjararum Kalibawang, Kulon Progo] [Undergraduate Thesis] Informatic, STIMIK AMIKOM, Yogyakarta, (2011). [in Bahasa Indonesia]. p. 2-10. http://docplayer.info/47548732-Perancangan-media-pembelajaran-berbasis-multimedia-pengenalan-seni-danbudaya-indonesia-pada-sd-negeri-blumbang-banjararum-kalibawang-kulon-progo.html

10. P. Indrias. Pembuatan CD interaktif pengenalan kebudayaan Indonesia berbasis flash. [Making interactive CD of introduction of flash based indonesian culture]. [Thesis] Fakultas Matematika dan Ilmu Pengetahuan Alam, Universitas Sebelas Maret Surakarta, (2010). [in Bahasa Indonesia]. p. 2-4. https://eprints.uns.ac.id/346/1/161812608201009491.pdf 
11. R.V. Aliniaina. How is encyclopaedia authority established? [PhD Thesis] University of Glasgow, (2013). p. 87-118. http://theses.gla.ac.uk/3414/1/2012RasoamampianinaPhD.pdf

12. C. Sherly. Perancangan grafis buku wisata budaya Tana Toraja beserta media pendukungnya. [Graphic design of Tana Toraja cultural tour book and its supporting media] [Undergraduate Thesis], Faculty of Art and Design, Universitas Kristen Petra, (2009). p. 26-34. [in Bahasa Indonesia]. http://repository.petra.ac.id/1832/

13. K. Lunn. Software Development Life Cycle. In: Software development with UML. London: Plagrave (2003). p. 53-68. https://link.springer.com/chapter/10.1007/978-0-230-80419-7_5

14. N. Khan, I. Yaqoob, I.A.T. Hashem, Z. Inayat, W.K.M. Ali, M. Alam, et al. Scientific World Journal, 2014(712826):1-18 (2014). https://www.hindawi.com/journals/tswj/2014/712826/

15. R. Muslimin. Journal of Asian Architecture and Building Engineering, 16(1):39-44 (2017). https://www.jstage.jst.go.jp/article/jaabe/16/1/16 39/_pdf

16. A. Nediari, G. Hartanti. Humaniora 5(2):1279-1294 (2014). [in Bahasa Indonesia]. http://journal.binus.ac.id/index.php/Humaniora/article/view/3271

17. S. Salam, M.S. Husain, Tangsi. Panggun Jurnal Seni dan Budaya, 7(4):284-292 (2017). https://simlitmas.isbi.ac.id/e-jurnal/index.php/panggung/article/view/280/pdf

18. R. Muslimin. Decoding Passura': Representing the indigenous visual messages underlying traditional icons with descriptive grammar. Open Systems: Proceeding of the 18th International Conference on Computer-Aided Architectural Design Research in Asia, 15-18 May. pp. 781-790 (Singapore, 2013). http://papers.cumincad.org/data/works/att/caadria2013 113.content.pdf 